\title{
Influence of Teacher-Student Relationship on Students' Indiscipline In Public Secondary Schools In Naivasha Sub- County, Kenya
}

\author{
Goodeve S.K Mwaniki, Prof. M. Ngunjiri, Dr. John Kanjogu \\ Department of Curriculum and Education Management, Laikipia University, Kenya.Correspondence:
}

\begin{abstract}
The purpose of the study was to assess the influence of teacher-student relationship on students' indiscipline in public secondary schools in Naivasha sub-county, Kenya. The study was conducted in 26 public secondary schools. The target population for the study compromised head teachers and teachers of public secondary schools in Naivasha Sub-county. Purposive sampling technique was used to sample head teachers while Krejcie and Morgan's (1970) table for determining sample size for teachers. A total of 195 respondents were targeted by the study (constituting 26 head teachers and 169 teachers) out of which 194 responded (constituting 25 head teachers and 169 teachers) giving a response rate of $99 \%$. Questionnaires were used as instrument for data collection. SPSS was used to analyze the data where both descriptive and inferential statistics were used. The analyzed data were presented in terms of graphs and tables. Results showed that teacher-student relationship had a significant negative relationship with student indiscipline in schools $(\mathrm{Phi}(\varnothing)=$ $-.796, \mathrm{p}=0.000)$. The Chi-Square $\left(\chi^{2}\right)$ statistic between teacher-students relationship and students' indiscipline was statistically significant $\left(\chi^{2}=321.248, \mathrm{p}=0.000\right)$. The null hypothesis $\mathrm{H} 01$ was therefore rejected at .05 level of significance. The study concluded that the higher the level of teacher-student relationship, the less the level of indiscipline in schools teacher-student relationship influences students' discipline in secondary schools in Naivasha Sub-County. It was recommended that schools should ensure that there is good relationship between teachers and students. By creating good relationship between teachers and students, the school environment may become conducive thus reducing the cases of indiscipline among students.
\end{abstract}

Key Words: School based factors, home based factors and students' indiscipline

\section{INTRODUCTION}

Education has received unmatched attention as the best method of achieving a country's economic and social growth. It is the living bud of a nation's development (Muchemi, 2005). If a nation wishes to achieve any form of development, her people must be well socialized though a defined education system. It is through the education system that nations impart to their people the aspirations that will produce the citizen of their choice. The Kenyan government together with other stakeholders in education has invested heavily in education. Consequently notable achievements have been realized in this country in enrolment and the increasing number of education institution at all levels (Muchemi, 2005).

Secondary school education in Kenya forms a transition stage between elementary education and higher education training and the eventual world of work (Koech, 1999). Besides successful completion and achievement of the learners at the end of the secondary school course, character building is also a vital concurrent concern (Mwikali, 2005). As such discipline and moral standards are fostered in schools as part of the development process and nurturing of future successful Kenyans. However, despite the efforts to maintain discipline in educational institutions, the problem of students' unrest and violence remains one of the most intriguing issues in the Kenyan education sector (Mwikali, 2005). Students' indiscipline has assumed alarming proportions and if not checked it would eat into the very fabric of our national entity (Kombo, 1998). Kombo further asserts that strikes and riots have become such a norm that it is becoming difficult to assess the cumulative impact of them not only on the affected schools and education sector but on the whole economy in general.

Students' riot creates a very bad learning and teaching environment. This is because they often result in destruction of teaching and learning facilities as well as loss of lives. This is in sharp contrast to the objective of a school whose main aim should be creation of an environment that promotes both teaching and learning process. Michemi (2006) asserts that a school environment that is safe, peaceful and free from student riots 
should be the effort of all the school management fraternity. Lockheed (1991) observes that an orderly school environment is closely linked with schools where teachers gain and hold the attention of their students, maintain discipline, begin and end lessons on time and evaluate student performance regularly. Besides interfering with the learning process, students stand in the way to harm the process of molding the youth into a productive member of the society, (Eshiwani, 2001). Eshiwani, in his view, students' strikes are a symptom of inability of the schools to cultivate relevant morals among the youth and this situation threatens socio-economic development of the nation.

Student strikes in most cases do not just happen because of several long standing issues which the school authority has either ignored or authority's response has not been satisfactory (Masese, 2007). In his view, in most cases, the consequences include incidences such as rape, violence, loss of school property, loss of lives and loss of school time due to frequent closures. This has in turn led to poor examination performances and also wastage of potential human resources due to expulsion. From this premise, it is clear that discipline is essential to smooth functioning of schools and society. Etizi (2008) defines discipline as a system of making the individual to make reasonable decision responsibly. He further says that the goal of discipline is to make it possible for the individual or a team of individuals to succeed in the set goals. It refers to the kind of order involved in trying to reach appropriate standards to follow appropriate rules for engaging in a valid activity. It requires freedom of choice and makes one to understand the consequences and is not imposed by authority figures but rather individual themselves (Charles, 1995). Therefore with discipline in our learning institutions, we would have very rare cases of the student strikes. Griffin (1994) asserts that sound discipline is an essential ingredient in the creation of a happy and industrious school community, performing properly its function of training the citizens of tomorrow.

The persistent occurrence and high frequency of student unrest in secondary schools is a clear indication that indiscipline is rampant and live hence an issue to be dealt with (Kiprotich, 2001). According to Majali (cited in Kiprotich, 2001) we must find what has gone wrong and that the wave of violence and indiscipline in school must disturb out sleep hence a need to come up with solution today and not tomorrow. In the same year (2001), the Ministry of Education appointed a task force whose mandate was to meet the stakeholders, gather views and information and make recommendations in order to stem out the culture of violence taking root in secondary schools (MoEST, 2001).

In spite of the governments, effort to stem out the culture of student unrest in schools, its occurrence still exhibits an upward trend. Makwetle (2006) observes that beyond the increase in occurrences, there is a significant change in the manner in which it takes manifestation.

In his view, students are resorting to acts of violence, going on rampage and arson, stone throwing and brick battling .The Nairobi chronicle of July $21^{\text {st }} 2008$ reported counselors saying that the post-election violence that left hundreds dead and close to half a million homeless may have taught teenagers that violence is a legitimate means of expressing long-held grievance (Nairobi chronicle, 2008). This is a problem and it gives a strong justification for a study to investigate the factors contributing to students' unrest in secondary schools and make appropriate recommendations so as to reverse the situation and make schools valued agents of development.

\subsection{Statement of the Problem}

Student indiscipline and the violence that tends to arise from it is a major problem around the world. There are numerous complaints from the society on the adverse effects and impacts of indiscipline on the perpetrator, victim, wider community and education. For many students, home and school environment has not been conducive to learning process as most of the children are denied human dignity and physical integrity and lack of equal protection under law that is accorded to adults (Etizi, 2008). In order to restore public confidence in schools and home as agents of character building and to eliminate the economic burden arising from student indiscipline, a systematic study is needed to investigate the influence of school and home based factors on students' indiscipline in public secondary schools. In this context, this study assessed the influence of teacherstudent relationship on students' indiscipline in public secondary schools in Naivasha sub-county, Kenya.

\section{LITERATURE REVIEW}

This section presents the theory used in the study and the relevant literature on the influence of teacherstudent relation on student's indiscipline and the theories used in the study.

\subsection{Theoretical Framework}

The study was grounded in Bandura's (1977) social learning theory whose relevance to this is explicated in this sub-section. The theory posits that people learn from one another via observation, imitation, modeling and reproduction (Bandura, 1977). Bandura earlier work focused on aggressive behaviour developed through social learning. Bandura based his initial theories on his observations on adolescents coming from 
families where the parents also displayed aggressive behaviour. Bandera concluded that violence is a learned behavior. Huesmann (1988) supports this view by saying that children learn aggressive behavior through both observational learning and enactive learning. He further says that there is a positive relationship between a child's observation of others behaving aggressively and the child behaving aggressively. In a school setting, students are exposed to different models that influence their behavior. Those whose models in the family unit are aggressive tend to become aggressive in school and are to participate in strikes and riots.Bandura's (1977) social learning theory further posits that people learn from one another through observation, imitation and modeling .Students are exposed to all manner of models in the family unit, society as well as the media. Students coming from families where the parents display aggressive behaviour are more likely to engage in aggressive behaviour in school and participate in strikes and riots. In addition, negative coverage of events by media can encourage violence and emulation of activities among the students culminating into school disturbance. This theory is very important in relation to the school situation, because it argues that persistent indiscipline is an indication of problems being experienced in social institutions (the school and family), and thus schools should adopt management styles like consultations that are acceptable to all.

However this form of modeling is not restricted to parents but to other type of models as well. According to Porter (2000), corporal punishment that is still in use in some schools may provoke students to retaliate against the teachers using it. Learners will therefore imitate the apparent aggression of the teacher by being violent or aggressive. In his view such learners are more likely to take part in strikes and riots. Moreover, students also imitate each other, a technique commonly referred as the "ripple effect" in which when one school goes on strike, other neighbuoring schools begin to imitate it thus becoming copycats. Besides imitating their parents and fellow students, learners have been found to imitate other adults as it happened in the year 2008 when a wave of students' unrest swept across the country (Kenya episcopal conference, 2008). Furthermore in that year (2008) more than three hundred secondary schools were closed due to unrest. The Kenya Episcopal Conference (2008) argued that the students were imitating what adults and their parents did in January and February of 2008 during the post-election violence.

\subsection{Teacher-student Relationship and Students' Indiscipline}

In Kenya the first case of student indiscipline was reported in Maseno in 1908 when students refused to participate in manual labour and pressed for more reading and writing (Anderson 1970). He further states that three years later Mumias School went on strike against colonial administration. The nature of student indiscipline in secondary schools in the last ten years is multifaceted and it involves behavior that is destructive to the individual students, school property and school community where such upheavals take place (Ngesu, 2011). He further states that students' indiscipline are characterized by turbulence, violence and destructive activities when the students have been provoked by anger by conflict situation in the school as witnessed in Kyanguli secondary school in the year (2001), and Gede secondary school in the year (2007) in Malindi to mention but just a few. Recently, several public schools in Naivasha Sub-County have experienced student's indiscipline. Some of these schools include Handa in the year (2010), Githirwa in the year (2010) and Naivasha boy's high school in the year (2010), District education office Naivasha (2010). Among the grievances highlighted by these students are intolerance or punitive administration and psychological factors, some of which were pegged on parenting styles.

The administration styles of school management in responding to some of the challenges emanating from student behavior tend to influence indiscipline across different location in other parts of the country, for example, the fire that gutted a dormitory of Upper High school and killed one form three student was the second attempt. The first one was foiled when boys at the school were caught attempting to torch the administration block (Koross \& Odalo, 2008). All these examples seem to suggest that student indiscipline stem from a combination of the different factors. The parenting styles and schools administration styles have been linked to erratic students' indiscipline and unrest in secondary schools in Kenya (Ndetei, 2007).

Macmanus (1989) and Reynolds (1989) support Mbiti's (1982) view by saying that one of the most significant in-school factors that influence students' discipline is the schools social environment or organization climate for that matter. This refers to the way members of the school community relate and interest with each other. If the climate is favorable, the members are likely to increase their level of interaction and consequently enhance the school's learning outcomes. The reverse is applicable. Members of a social organization do not act in a vacuum but on the contrary their actions are integrally related to the organization's managerial policies. This implies that the extent to which members of the school community will direct their effort to the laid down goals depends on the kind of organizational climate created by the principal as the schools' chief executive. In this regard, if he/she applies a democratic/inclusive approach, teachers and parents are likely to play a proactive role in nurturing learners' behavior towards the desired direction and vice versa (Pollard, 1982).

Eshiwani (1994) observed that Principals of good performing schools are ever present, fully involved in organizing the learning process in their schools and participate in the actual teaching process and always 
familiar with the on-goings in their schools and classrooms. This implies that the administrative and leadership style of a Principals related to the discipline in their schools. Principals who tend to employ democratic and participatory styles, encouraging communication and expression are more effective than those with autocratic tendencies. However due to the colonially inherited school administration styles of strict discipline and rigid rules, there is rampant use of autocratic style. In most secondary schools there is emphasis on blind obedience to school authority that is enforced through prefects and teachers. This has resulted in poor flow of orders and communication from the top to the bottom without any corresponding channels for bottom-up responses (Gathiari, 2002). In Gathiari view, such autocratic communication has been attributed to the rise of indiscipline and strikes in schools. He further asserts that breakdown in communication means that student's views are not listened to and this leads to anger and violence.

In most schools, the rules and regulations are deliberately designed to inculcate fear in students and reduce the capacity of students to have any say in the school's running (Koros \& Odalo, 1988). In Koros and Odalo view, suspensions, expulsions and other forms of punishment are arbitrarily dished without adequate opportunity for students to have a say. This leads to students becoming intolerant to the resulting humiliation and oppression brought by the rules. The consequences of this are revolt and strikes that do not care or give regards to the consequences of such action (Koross \& Odalo, 1988). Kinyanjui (1975) asserts that there is need for urgent shift from the style that makes students passive recipients of knowledge to those that make participants in the process of learning as well as running the school. Koech (1999) identified the misappropriation of school funds and resources as a cause of student strikes. This misappropriation leads to shortages of essential facilities and stuff such as food and water because schools are forced to operate on shoe strings budgets. Misappropriation of fund and school resources is often a product of poor accounting procedures, practices and capacities in school as well as lack of timely auditing of schools that allows many financial malpractices to flourish. The misappropriation is also caused sometimes by the lack of clear guidelines regarding the recruitment and retaining of non-teaching staff in schools who often strain the little resources in a school (MoEST, 2001). Besides misappropriation of funds, shortage of teaching staff in some schools has been described as a major cause of strikes (Koech, 1999).In his view in such schools there is also lack of necessary teaching and learning facilities. He further states that the lack of both human and physical facilities leads to discontentment especially in a situation where poorly equipped schools exists side by side with privileged overequipped and over staffed schools.

A number of researchers have conducted research on head teachers' training needs and made various recommendations. For example, Okumbe, 2001) recommended that for purposes of effectiveness of school teachers, school managers and curriculum implementers, an effective in-service training should be provided to them. This recommendation was made in the understanding that the appointment of Principals has generally been done on the basis of teachers' experience in the work place, at the expenses of considering whether they have undergone training to prepare them for their new roles before assuming office. Mutai (2003) underscored the need for effective school management and reported that the promotion of teachers to a position of responsibility should be pegged on having undergone a pre-service training on his/her new roles. However, the appointment of head teachers in Kenya is based on years of service, rather than on having to undergone training on their roles before taking up the post. Okumbe (2001) observed that appointments of principals is done on the assumption that the preserve professional training that they underwent to prepare them for teaching, coupled with the experience that they get as practicing teachers are enough to enable them discharge their roles effectively. It is assumed that when the newly appointed principals assume office they will learn on the job and that they will attend in -service training to equip them with emerging managerial challenges. However from the principals' own experiences and in view of how they have been discharging their roles, it raises questions about their preparedness in this respect (Eshiwani 1993). Eshiwani, (1993) and Okumbe (1999) agreed that training improves workers' effectiveness in discharging their functions. It is therefore important that training needs for school Principals are addressed immediately one is appointed. This would render them effective in discharging their managerial duties such as implementing educational policies.

The role of guidance and counseling in the administration and management of student discipline in Kenya has been recognized by various government policy documents since independence. The report of the National committee on Educational objectives and policies of 1976 recommended that guidance and counseling be taught using subjects like religious education and social education and ethic to enable the school promotes the growth of self-discipline among students (Gachathi, 1976). Despite this recommendation, the use of guidance and counseling services was still wanting in helping curb indiscipline in schools. Kenya schools were advised to strengthen the guidance and counseling departments particularly in the year 2002 to fill the vacuum left by the ban of corporal punishment (MoEST, 2001). Corporal punishment was banned in Kenyan schools in the year 2001 through legal Notice No. 56 of Kenya Gazette (supplement No. 25:199 of 30 $0^{\text {th }}$ March, 2001). This legal notice effectively repealed legal notice No. 40 of 1972 which had introduced corporal punishment into the education Act. Since the ban of corporal punishment was done abruptly, Kenya secondary schools experienced 
enormous indiscipline problems. Teacher counselors were expected to come in handy to help tackle these indiscipline problems. However, teachers had not received professional training in counseling to enable them carry our professional counseling (Mutie, 2004).

Several studies have been conducted to investigate the extent to which guidance and counseling programmes have been implemented (Abdi, 2008).In his study, it was discovered that most teachers are incompetent and did not know exactly how to guide and counsel students. Abdi (2008) asserts that guidance and counseling departments in our schools are not fully empowered and there is lack of a formal structure to enable the department to perform its roles effectively. Research carried out by Mutie (2004) on how teacher counselors are selected in secondary schools revealed that many are appointed by the Teachers Service Commission to head the department. In his view, there is no consideration of whether the teacher is trained or not and the appointment is like any other in the school. Therefore, such teachers are ineffective because they are not trained and are not aware of their role in guidance and counseling. The Kamunge report of 1988 recommended senior teachers to supervise guidance and counseling programmes that were in place in secondary schools (Kamunge, 1988). However, the report did not recommend any training for such teachers. This led to more failure in the guidance and counseling department in its pursuit to offer services. In the year 2001, Ministry of Education Science and Technology (MoEST, 2001) made recommendations on in-service courses and short time seminars were to be organized and coordinated by the guidance unit at KIE. The recommendations however were not good enough because counseling requires more than just short courses and seminars since it deals with human behaviour which is quite complex. Therefore, lack of effective guidance and counseling services in schools has been one of the major contributing factors to students' unrest. Stima (1987) asserts that indiscipline could be minimized if effective guidance and counseling services are offered. Therefore strengthening guidance and counseling services is one of the most effective proactive ways of deflating violent students' unrests.

The education system in Kenya has historically placed emphasis on academic performance aimed at getting white collar jobs. Secondary schools are evaluated by the public on how many students qualify for admission to the public universities whereas primary schools are judged on how many students are eligible for admission into the highly valued government funded secondary schools. Teachers and students alike are therefore pressurized to attain high grades and those who are seen to perform below parental and government expectations are judged harshly (Khamasi, 2007). The report on the task force on students discipline and unrest in secondary schools in September 2001 observed that the current curriculum does not wholly address the policy objectives and philosophy of education (MoEST, 2001). In its implementation, teachers tend to be more exams oriented. In addition, the curriculum does not cater for the holistic development of the child. It further noted that the curriculum is still loaded despite the current reduction of the number of examinable subjects. Mwikali (2005) asserts that when curriculum is not properly implemented and supervised, it pauses a big challenge to both staff and student personnel which can even translate into school strike due to Pessimism that comes off a result as inadequate coverage of the syllabus which leads to poor examination. Normal teaching in schools is sometimes disrupted by teachers' shortage as well as adequate teaching facilities. In such situations, students find themselves idle and bored making them highly irritable. Consequently, such students can become violent at the slightest provocation leading to school unrest (Institute of Policy Analysis \& Research, 2008).

\section{Methodology}

This study was carried out in public secondary schools in Naivasha Sub-county of Nakuru County, Kenya. The Sub-County has 29 public secondary schools. Ex-post facto research design was used in the study. The target population for the study compromised head teachers and teachers of public secondary schools in Naivasha Subcounty. In total the study targeted 26 head teachers and 286 teachers. Twenty six (26) principals were purposively sampled to participate in this study. The sample for the teachers was based on Krejcie and Morgan's (1970) table for determining sample size (n) from a given population (N), the study sampled 169 teachers (n) from a total population of 286 teachers $(\mathrm{N})$ in the study area.

Data was collected through a self-administered questionnaire. Two sets of questionnaires, one for head teachers and the other for teachers were used to collect the data. The scoring in the questionnaire was done using a tick against the statement given in scale from definitely true, true, undecided and definitely not true. Primary data from the field were edited to minimize errors made by respondents. Coding was done to translate question responses into specific categories. The coded items were analyzed with the aid of a computer on SPSS. Normal scale data, specifically data on respondents and school characteristics were analyzed using frequency counts and percentages. Descriptive statistics such as frequencies and percentages were used while inferential statistics such as chi-square was used to test the relationships between the study variables.

\section{Findings of the Study}

This section presents the findings of the study on the influence of teacher-student relationship on students' discipline 


\subsection{Level of Students' Indiscipline in Secondary Schools in Naivasha Sub-County}

To establish the level of students' indiscipline, teachers were asked to indicate the level of students' indiscipline in their schools. The findings are as presented Figure 1.

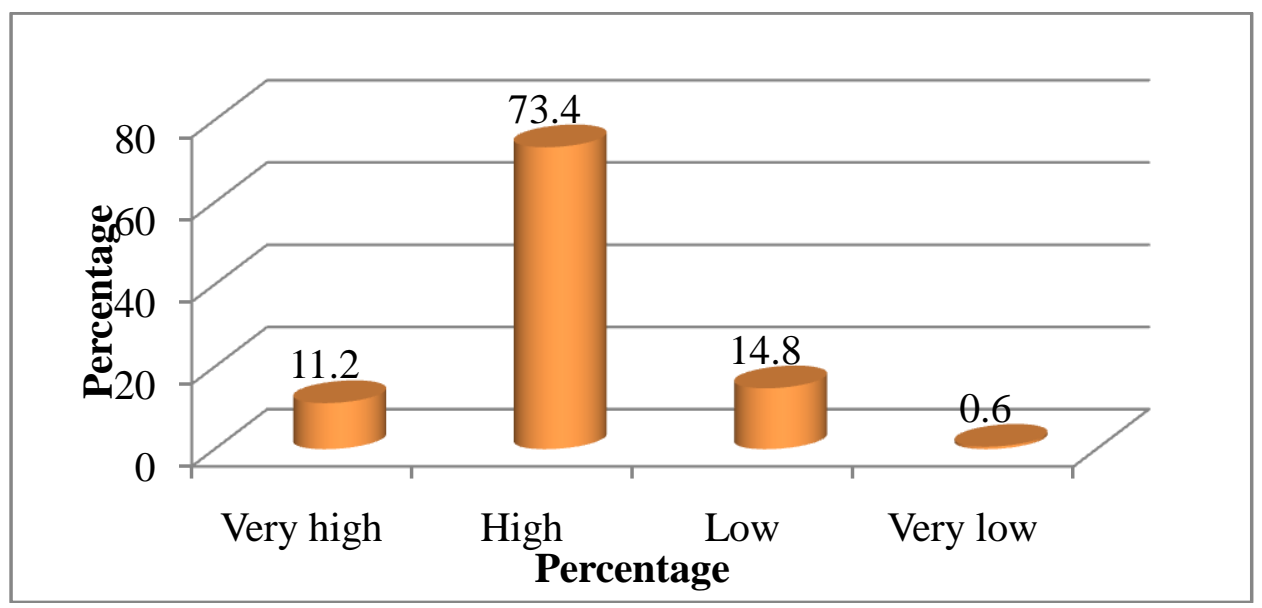

Source: Field data (2015)

Figure 1: Level of Students' Indiscipline in Secondary Schools in Naivasha Sub-County

The data in Figure 1 show that there was high level of students' indiscipline as indicated by $73.4 \%$ of the respondents. The study also found that $14.8 \%$ indicated that the level of students' indiscipline was low, $11.2 \%$ indicated that indiscipline among students was very high while $0.6 \%$ indicated that the level of indiscipline among students was very low. These findings are in line with the findings of Ngesu (2011) who found that the nature of student indiscipline in secondary schools over the past years is multifaceted and involves behavior that is destructive to the individual students, school property and school community where such upheavals take place.

\subsection{Influence of Teacher-Student Relationship on Students' Discipline}

To establish the influence of teacher-students relationship on the students' indiscipline, teachers were asked to indicate the truth indifferent statements. The findings are as presented in Table 1.

Table 1: Influence of Teacher-Student Relationship on Students' Discipline

\begin{tabular}{|c|c|c|c|c|c|c|c|c|c|c|c|c|}
\hline \multirow[t]{2}{*}{ Statement } & \multicolumn{2}{|c|}{$\begin{array}{l}\text { Definitel } \\
\text { y true }\end{array}$} & \multicolumn{2}{|c|}{ True } & \multicolumn{2}{|c|}{$\begin{array}{l}\text { Undecide } \\
\text { d }\end{array}$} & \multicolumn{2}{|c|}{ Not true } & \multicolumn{2}{|c|}{$\begin{array}{l}\text { Definite } \\
\text { ly not } \\
\text { true }\end{array}$} & \multicolumn{2}{|c|}{ Total } \\
\hline & $\mathrm{f}$ & $\%$ & $\mathrm{f}$ & $\%$ & $\mathrm{f}$ & $\%$ & $\mathrm{f}$ & $\%$ & $\mathrm{f}$ & $\%$ & $\mathrm{f}$ & $\%$ \\
\hline Some teachers abuse & 2 & 16.6 & 6 & 38.5 & 1 & 8.3 & 5 & 32 & 8 & 4.7 & 16 & 10 \\
\hline students & 8 & & 5 & & 4 & & 4 & & & & 9 & 0 \\
\hline Teachers threaten & 3 & 18.3 & 7 & 41.4 & 1 & 8.3 & 5 & 29.6 & 4 & 2.4 & 16 & 10 \\
\hline $\begin{array}{l}\text { students that they } \\
\text { will fail }\end{array}$ & 1 & & 0 & & 4 & & 0 & & & & 9 & 0 \\
\hline $\begin{array}{l}\text { Teachers do not } \\
\text { encourage and } \\
\text { motivate students to } \\
\text { do well }\end{array}$ & $\begin{array}{l}6 \\
2\end{array}$ & 36.7 & $\begin{array}{l}8 \\
2\end{array}$ & 48.5 & 6 & 3.6 & $\begin{array}{l}1 \\
7\end{array}$ & 10.1 & 2 & 1.2 & $\begin{array}{l}16 \\
9\end{array}$ & $\begin{array}{l}10 \\
0\end{array}$ \\
\hline $\begin{array}{l}\text { Sexual advances by } \\
\text { teachers }\end{array}$ & $\begin{array}{l}5 \\
9\end{array}$ & 34.9 & $\begin{array}{l}6 \\
8\end{array}$ & 40.2 & $\begin{array}{l}2 \\
2\end{array}$ & 13.0 & $\begin{array}{l}1 \\
8\end{array}$ & 10.7 & 2 & 1.2 & $\begin{array}{l}16 \\
9\end{array}$ & $\begin{array}{l}10 \\
0\end{array}$ \\
\hline
\end{tabular}

Source: Field data (2015).

The data in Table 1 show that $48.5 \%$ indicated that it was true that teachers do not encourage and motivate students to do well. The findings also revealed that $41.4 \%$ of the respondents indicated that it was true that 
teachers threaten students with failure, $40.2 \%$ indicated that it was true that there was sexual advances by teachers and that $38.5 \%$ indicated that it was true that some teachers abuse students.

\subsection{Hypotheses test on Teacher-student relationship and students' indiscipline}

The objective of the study was to find out whether there is any statistically significant relationship between teacher-student relationship and students' indiscipline in public secondary schools in Naivasha subcounty, Kenya. In order to achieve this, the null hypothesis was formulated and stated as follows:

H01: There is no statistically significant relationship between teachers-students' relationship and students' indiscipline in public secondary schools in Naivasha sub-county, Kenya.

The findings in this study therefore presumed that teacher-student relationship is not linked to students' discipline. To ascertain the truth of this preposition, the hypothesis was tested using $\chi^{2}$ statistic whose results are shown in Table 2.

Table 2: Teacher-student relationship and students' Indiscipline

\begin{tabular}{lllll}
\hline & Value & df & Phi $(\varnothing)$ & $\mathrm{P}$ \\
\hline Pearson Chi-Square & $321.248^{\text {a }}$ & 12 & -.796 & .000 \\
N of Valid Cases & 169 & & & \\
\hline \multicolumn{4}{l}{ Note: ${ }^{*}$ means } & significant at .05
\end{tabular}

Table 2 shows that there was a significant negative relationship between teacher-student relationship and students' indiscipline in schools (Phi $(\varnothing)=-.796, \mathrm{p}=.000$ ). The chi-square test statistic was also found to be significant $\left(\chi^{2}=321.248, \mathrm{p}=.000\right)$. Therefore, the null hypothesis that there was no significant relationship between teacher-students' relationship and students' indiscipline was rejected at .05 level of significance. It can therefore be concluded that teacher student- relationship is related to students' indiscipline in schools. The findings in this study are in line with that of Tumutoreine (2003) who found that most unrest in schools are due to poor teacher-student relationship, which includes aspects of psychological defects. The defects may entail hurting student when they realize that they are constantly ignored by those people who have an important role to play in their lives like parents and teachers.

\section{SUMMARY OF THE FINDINGS OF THE STUDY}

Teacher-student relationship had a significant negative relationship with student indiscipline in schools (Phi $(\varnothing)=-.796, p=0.000)$. The Chi-Square $\left(\chi^{2}\right)$ statistic between teacher-students relationship and students' indiscipline was statistically significant $\left(\chi^{2}=321.248, \mathrm{p}=0.000\right)$. The null hypothesis H01 was therefore rejected at .05 level of significance.

\section{CONCLUSIONS}

From the findings of the study, it was clear that teacher-student relationship had statistically significant influence on students' indiscipline. It can therefore be concluded that the higher the level of teacher-student relationship, the less the level of indiscipline in schools.

\section{RECOMMENDATIONS}

The study recommends that schools should ensure that there is good relationship between teachers and students. By creating good relationship between teachers and students, the school environment may become conducive thus reducing the cases of indiscipline among students.

\section{REFERENCES}

[1] Anderson J. (1970).The struggle for schools. London: Longman publishers.

[2] Bandura, A. (1977).Social learning theory. Englewood Cliffs, NJ; Printice Hall.

[3] Charles, L. (1995). Drug behaviour and modern society (2 ${ }^{\text {nd }}$ Edition). Boston: Edward and Arnold.

[4] Eshiwani, G.(1993) .Education in Kenya since independence. Nairobi: Education Publishers.

[5] Etizi, M. (2008).Effective student discipline: Methods for teachers. Nairobi: Shrend Publishers.

[6] Gachathi, P. (1976).The national committee on education objectives and policies. Nairobi: Government printers.

[7] Githiari, F. (2002,). A survey of student strike in selected schools in Nairobi Province. (Unpublished Master's Thesis), University of Nairobi, Kenya. Retrieved 7 20, 2013, from www.cisanewsafrica.org:http//www.cisanewsafrica.org.

[8] Huessmann, L. \& Miller, L. (1994). Aggressive behavior: Current perspectives. New York: Plenun Press 
[9] Kamunge Report (1988). Kenya education commission. Nairobi,Government printer.

[10] Khamasi, J.(2007, April). Students discipline and the need for pedagogical sensitivity. Paper presentation at Kenya Association of Educational and Administration management 2007 conference. Eldoret: AMEACEA/GABA pastoral institute.

[11] Kinyanjui, P. (1975). Secondary school strikes: The art of blaming the victim. Working Paper No.2008 Institute for Development studies, p1

[12] Koech, D. (1999). Report of the commission of inquiry into education systems in Kenya. Nairobi: Government Printers.

[13] Kombo, D. (1998).Correlates of students' defiant behavior in selected secondary schools in Nairobi.( Unpublished master's thesis). Kenyatta University, Nairobi.

[14] Koross, K \& Odalo, P (2008, July 14). Learners use arson to air their grievances. Daily Nation, p 15865.

[15] Lockheed, M. (1991) .Improving education. Education Review.16 (3)303-311.

[16] Macmanus, M. (1989). Troublesome behaviour in the classroom: A teacher survival London: Routledge Publishers.

[17] Makwetle, A. (2006) .Causes and manifestation of aggression among secondary school Learners (Unpublished master's thesis). University of South Africa, Pretoria.

[18] Masese, A. (2007).A Study of the causes of Drug Abuse Among students in selected Secondary schools in Kisumu Municipality, Kenya.( Unpublished master's thesis). University of Nairobi,Kenya,

[19] Mbiti, D. (1974) .Foundation of school administration. Nairobi: Oxford University Press MoEST (1999).School management guide, Nairobi: Jomo Kenyatta Foundation

[20] MoEST (2001). Report of the task force on student discipline and unrest in secondary schools. Nairobi: Jomo Kenyatta foundation.

[21] Muchemi, W. (2005 June 22).Education the living bud of a nation's development. Daily Nation, p23.

[22] Mutai, K. (2003, March 7).Training of teachers before being promoted to be educational administrators. Daily Nation,p24.

[23] Mutie, M. (2004).Attitudes of secondary school head teachers towards guidance and counseling as a disciplinary tool: A case study of central division, Machakos district. (Unpublishedmaster'sthesis).University of Nairobi, Nairobi.

[24] Mwikali, S. (2005) .Factors influencing school strikes in central division- Machakos district. (Unpublished master's thesis). Kenyatta University, Kenya, Nairobi.

[25] Ndetei, D. (2007).Bullying in public secondary school in Nairobi, Kenya. Child and Adolescent Mental Health, 19 (1)45-55

[26] Ngesu, L. (2011). Students militancy in secondary schools in Kenya: A Social analysis of its causes, manifestations and consequences. (Unpublished Doctoral thesis).Dar Es Salaam University, Dar Es Salaam.

[27] Okumbe, J. (2001). Human resources management perspective. Nairobi: Educational Development and Research Bureau.

[28] Pollard, T. (1982). Structure and polymerization of Acanthamoeba .London: Open University press.

[29] Porter, 1. (2000). Behaviour in schools. London: Open University press. 